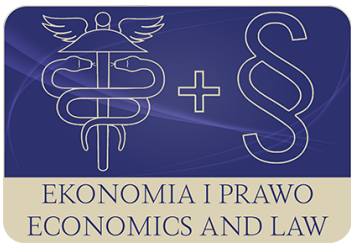

EKONOMIA I PRAWO. ECONOMICS AND LAW

Volume 19, Issue 1, March 2020

p-ISSN 1898-2255, e-ISSN 2392-1625

www.economicsandlaw.pl

EKONOMIA I PRAWO
ECONOMICS AND LAW

ORIGINAL ARTICLE

received 13.07.2019; revised 13.01.2020; accepted 31.03.2020

Citation: Nowak, K. (2010). The state of truth in the context of globalization. Ekonomia i Prawo.

Economics and Law, 19(1): 85-97. doi:10.12775/EiP.2020.007.

\title{
The state of truth in the context of globalization
}

\author{
KAROLINA NOWAK \\ Poznan University of Economics and Business, Faculty of Economy, Department of Sociology \\ and Business Ethics, al. Niepodległości 10, 61-875 Poznań, Poland \\ $\square$ karolina.nowak@ue.poznan.pl \\ D orcid.org/0000-0002-2091-8965
}

\begin{abstract}
Motivation: This article addresses the issue of the functioning of modern societies in the context of worldview transformations related to globalization processes. Whether today's globalization processes - the dissemination of specific models, designs, systems, tools and narrations in socio-cultural-economic-political dimensions - have significantly redefined the notion of truth and strengthened (or perhaps weakened) its validity (phenomenon)? The main motivation to undertake this research was the desire to show the role and the strengthening of value (truth) in social practice, in particular in relation to scientific and economic practice.

Aim: The purpose of the article is to answer the question how globalization (in the socio-economic-cultural aspect) affects new ways of redefining the truth, treated as the axiological basis of scientific practice. The economic aspect has been taken into account in particular in the context of the establishment of a new (technological) approach to truth based on globalization processes taking place within the framework of network economics and on-demand economy. The literature review reconstructs two historically significant ways of redefining truth as the base value for scientific practice (autotelic and socio-useful) in order to show the breadth of socio-economic changes associated with the new definition of truth (as a technological value). The article is theoretical, based on philosophical considerations, recognized in a cultural perspective; the humanistic interpretation was applied.

Results: The result of the research is to show: 1 . the continuity of the process of redefining the truth, 2. the need to take into account the axiological context in relation to new types of economic practice.
\end{abstract}


Keywords: values; truth; globalization; access economy; culture JEL: J17; K38; Z1

\section{Introduction}

In their life, one encounters various situations in which the axiological aspect arises. Values are present in our lives in each and every choice, conversation, action. Out of all values, the truth stands out as the one that seems to be one of the most important, lasting and regulating values of our actions; one that has 'the most to say' in our lives (Winfield, 2001, pp. 20-25). Questions about truth - what truth is, what its foundations are, whether truth is discovered or constructed by human beings, what it is for philosophers, scientists and representatives of the so-called 'wide circles', why truth is so important, what it is associated with - have been presented in the philosophical, cultural, social and economics reflection for a long time. The main objective of the article is to show how globalisation, meaning the dissemination of specific patterns, as well as cultural and socio-economic policy solutions, affects new ways of redefining truth, recognized as the axiological basis of a particular sector of social practice, i.e. scientific practice. As a development of this goal, I am also investigating how technologized understanding of truth is socially rooted (i.e., it is becoming more widely socially accepted) through globalization processes occurring within the framework of network economics and on-demand economy (i.e. access economy).

\section{Literature review}

The inspiration for the study presented here, a distinction between the notion of truth and the phenomenon of truth, was provided by Tuchańska (2012) in the book Why truth? Truth as a value in art, science and everyday life. Tuchańska (2012, p. 12) notes that, as 'the notion of truth transcends the boundaries of philosophical subdisciplines, the boundaries between logic, logical semantics, epistemology, metaphysics, ethics, and even aesthetics', the phenomenon of truth is revealed in its constant presence in every aspect of human life. Why is this value important in human life? Why did we give it such a rank that - as Foucault wrote about the nietzschean imperatives of truth — we walk on its side all the time?

The starting point for studying the 'condition' of truth (both as a concept and as a phenomenon) in the context of modern globalization processes is the statement that this value is a foundation. That is to say, it regulates actions taken in a specific sector of social practice, i.e. scientific practice (it is the point of the activities undertaken by scientists), and is associated with cognitive valuation. Truth is a regulatory idea for science-based activities. The research undertaken in this part includes the analysis of selected examples of the redefinition of truth formulated on the basis of the broadly understood Euro-Atlantic cul- 
ture, whose definitions can be treated as: firstly - showing the phenomenon of truth, that it is subject to the process of universalization, and secondly the cultural 'path' to the emergence of a new approach to the truth.

\subsection{The cultural background of truth which is autotelically understood}

The autotelic, self-understood value is an inherent value, which is an objective in itself, in contrast to the instrumentally or pragmatically-treated value. On the basis of scientific knowledge, it is possible to identify precisely the functioning of the truth as a self-test, an autotelic value, which is the chief cognitive cognition of science, desirable as such, because it is true, and hence irrespective of determining a particular cognitive situation as a place of implementation and irrespective of any external function attributed to it, e.g. a pragmatic, technological or consensual one.

The answer to the question of why the truth recognised as an objective in itself as a scientific activity was and still is treated as 'sacred' in science, as the determiner of actions undertaken by the investigators is, in my opinion, hidden in the current common conviction that scientific cognition is the best way to know reality. This belief, dating back to the time of the Enlightenment, was (and still is) an important determinant of scientism as a worldview of science. On the basis of the scientistically understood science truth is treated as the central, overriding cognitive value, whereas the terrain where this value is fully realized, that is, where cognition is true in the sense of being compatible with the so-called objective reality (which exists independently of the awareness of this fact by the person who is aware of it), is a research practice of natural sciences (Maddy, 2007, p. 30). Scientism as a philosophical way of thinking about scientific cognition marks its presence in its various historical incarnations, such as the classical positivism, the antipositivistically oriented Husserl's phenomenology or the antipositivistically-oriented Popper's critical rationalism. The functionality of the scientistic valorisation of philosophical cognition is always researched historically in the context of specific circumstances, accompanying the development of research practice. The scientistic ideal of scientific cognition was broken, as it is known, in the 60s of 20th century and his historical return in the philosophy of science (Kuhn, 2009, p. 115).

A scientistic thesis, the standard according to which the highest epistemological qualification in the realization of the value of truth should be attributed to scientific cognition, can be included in the form of several methodological directives (MD), indicating how it is implemented (it is the most effective method of scientific cognition):

- MDl: In order to improve the scientific knowledge of reality in terms of being effective toward other types of cognition, it is appropriate to use methods that allow direct access to the tested reality, access by the eye (observation, experience sensory); 
- MD2: In order to improve the scientific knowledge of reality in terms of being effective toward other types of cognition, methods which allow achieving the highest degree of performance relative to the subject of cognition (cognition consistent with reality) should be used;

- MD3: In order to obtain specific results of cognition indicated above, scientific knowledge should be used as an exclusive instrument.

The directive belief of the first type (MDl), one that to know reality better and more effectively (or scientifically), methods that allow direct access to this reality should be used, is the basis for defining truth as something to be discovered. What is in fact - this conviction has found its fullest expression in the correspondent theory of truth. The development of this belief began already in antiquity, leading to an ancient ontologisation of the notion of truth, namely the translation of the world by the notion of truth (Parmenides, Protagoras, Plato, Aristotle). Aristotle expressed in his classical definition of truth a certain sphere of public awareness - social experience, including the beliefs that human beings, in the form of generations, described the way of proceedings, ensuring the achievement of certain effects:

- cognition of reality follows through a specific (reality) thought-reaching reality: truth and falsity from the point of view of things depend on their connection or separation. Who, then, thinks of the separable that is separated and of the connected that it is connected, tells the truth, while it is false when he or she thinks on the contrary about this state of things (ontological sense); - cognition of reality follows through a specific (true to reality) verbal outreach to reality: to say that what is is not and what is not is false and to say that what is is and what is not is not is true (the semantic sense).

These beliefs also underpin the medieval ontological and theological aspect of the notion of truth, when the world learns and interprets with the attributes of God - the existence of what is true is connected with cognizable reason (Anselm, Augustine, Thomas Aquinas).

The second type of directive believes (MD2), according to which such methods should be used to achieve the highest degree of performance relative to the subject of cognition (reality-compliant, reflected-reflection), reflects for example in the functioning of the truth in the formal logic. The logical description of the world becomes the best way to know it. In the logic, the truth is placed as one of the values used to formalize sentences (Andreas \& Schiemer, 2016, pp. $1-8)$. The classic account of sentences and predicates is based on two values (next to truth and falsity), which allow one to assign logical values to the tuple of sentences. As Nowakowski points out, the logical value in this case "entered' is, however, the 'back door' and the philosophical reflection on what is true is important of this system. A similar situation is also present in the case of the semantic concept of truth of Tarski (1995, p. 267), who, moreover, explicitly expressed it in the Logical-philosophical writings: 'I do not think there is something like "philosophical problem of truth". In the context of logical semantics, it is necessary to deal with relationships 'between certain language 
expressions and objects, the states of things to which these expressions relate' (Tarski, 1995, p. 236), and the mere truth is only for a given language with a given interpretation in model. This definition defines the extent of the notion of truth (the condition under which the sentence formula is true) and not its content (what is the truthfulness of the sentence formula). A truthful predicate, indicating the class of true sentences in a given language, is a distinguished method of adequacy, but the mere fact of getting to reality - item - appears earlier, i.e. assuming that "every sentence means that it has exactly one meaning and that the expression of the expressions on the meta-language retains the meanings of these expressions' (Tuchańska, 2012, p. 42).

The so-defined correspondence theory of truth has been criticised primarily for the notion of conformity appearing in it (sentences with fact, thoughts with reality) - the best demand for clarification of this ambiguity was expressed by Gottlob Frege in his concept of truth as a sense of sentence and the existence of truth in 3. Kingdom (think true objectively). The Polish development of this thought appears in Łukasiewicz, for whom the sentences differ in content, having the same object: Truth or Falsity. DM2 conviction was expressed in formal logic and logical semantics in the indication that it is precisely the logical description of reality that is the best way of knowing and referred to me as the examples of the concepts of truth (other possible examples: Russell theory of correspondence as a conformance to the conviction with some associated complex, Wittgenstein - the structure of the court replicates the structure of what the court concerns, Carnap - the definition of truth is connected with the program of transforming philosophy into a logical syntax of language) (Woleński, 2007).

The third directive (DM3), (which indicates scientific cognition as the best way of knowing reality), has accompanied philosophical-methodological reflection of science since its existence as a social research practice, i.e. the 17th century. This belief has led to the separation of substantive and methodologically different scientific disciplines, when individual sciences (especially mathematically taught) specialised in the description and examination of sections of reality. As Kotowa (2001, p. 150) observes, up to 60. 20th century the dominant trend in philosophical-methodological reflection on science was the one in which 'it is assumed to be a significant differentiator of scientific knowledge, scientific cognition, the criterion of an epistemological nature; it is usually truth'. It occurs both in a strong version (truth as a constituent element of scientific cognition) and a weaker one (the truth as the regulatory idea of scientific cognition the way Popper understood the truth).

It is worth noting that the philosophical background of the concept of truth, in which it is recognized autotelidly, as an epistemological myth in scientific cognition, reconstructed previously by me in the form of distinguished normative and directive beliefs and indicated in relation to selected examples of defining truth under the philosophy of science, is of course still functioning. Another cultural transformation, accompanied by the definitions of truth in the next part 
of the article, is not a negation of the belief that scientific cognition is the best knowledge of reality, but a kind of continuation that corresponds with it.

\subsection{The cultural background of socially utilitarian truth}

The truth in this sense is, most generally, to enable collective coexistence. It is a base of community functioning, a basis for co-operation with others. As Kołakowski (2009, p. 188) writes, in this regard truth is less about the truth itself and more about truthfulness. 'Truthfulness is originally a utilitarian value, it belongs to a resource in the social contract model as one of the most important measures to ensure the minimisation of conflicts and to enable collective bargaining in general'. The truth, as a socially utilitarian value, is therefore simply trust, based on which the human being coasts with others in the world.

The cultural transformation, linked to the functioning of community co-operation, would, therefore, be convinced that the best way of knowing reality is the scientific cognition that contributes to a better coexistence of collectivity, which creates the community and allows for a better life. This conviction is linked to the 19th century industrial revolution, which, on the one hand, led to the problem of demographic explosion and, on the other hand, 'entered' the human being into a new axiological context in which the role and importance of the work machinery, became crucial for human existence.

In the philosophical-methodological reflection, one of the expatriations of believing that the best way to know reality is scientific cognition that contributes to a better coexistence of the collective could be the concept of truth, which was formulated on the ground of pragmatism. As James (1983) claims, the court is true when it is usable. As James (2001, p. 226) writes in his example: 'if you ask me what o'clock it is and I tell you that I live at 95 Irving Street, then my answer may indeed be true, but you don't see why it is my duty to give it. A false address would be as much to the purpose', whether the sentence is true does not entail any compatibility with reality, only with what works, which has its positive results. Veracity therefore implies the verification: 'truth for us is simply a collective name for verification-processes, just as health, wealth, strength etc., are names for other processes connected with life, and also pursued because it pays to pursue them. Truth is 'made', just as health, wealth, and strength are made, in the course of experience' (James, 2001, p. 220). The pragmatic concept of James' truth is an expression that has been shaping since the mid-19th century modernist worldview, according to which the industrialization of the world, on the one hand, helps individual in life and makes her and him proud that individual created the machines that work for her/him, and, on the other hand, it controls, depreciates and enhances the sense of alienation. The fact that, according to James, truth is something that individual creates, formulating the ideas according to which she/he works, and the effectiveness of this action testifies to their truthfulness has its cultural source in the social experience of the turn of the 19th and 20th centuries, in which this experience 
has focused on generalised beliefs, which determine how to proceed to achieve the effect. It should be useful for ourselves and others to be produced in such a way that what we create contributes to a better coexistence in the collective part of which we are.

Globalization processes related to the dissemination of the pattern of an open society, in which 'rambling' the social ladder is possible, strengthened the understanding of the notion of truth as a socially useful value. The belief that the best way to know reality is scientific knowledge, which in practice builds community bonds and allows it to be better life, seems also to be a cultural source for the formulation by Habermas (2002) of the project Verite $\bar{a}$ Faire, the truth to do, the truth produced. The truth is treated here as a means of implementing a specific 'interest'.

\section{Methods}

The cognitive perspective adopted here is a cultural prospect. The rationale for choosing this research perspective is that it offers specific research tools to show the conditionality of truth, taking into account modern transformations (globalisation) of the world. I used hybrid text processing. During the first stage of searching texts about truth, a shallow text processing was used. The components of the deep text processing were used in the initial processing of data needed to obtain the necessary information to use a humanistic interpretation.

The theoretical and methodological basis of my deliberations is the socio-regulatory concept of culture. Culture is recognized here as a mental, ideological reality, thought-out as super-unit nature; it is universally respected (less widely accepted) normative-directive beliefs that govern various activities that members of a collective group undertake, both individually and socially (Kmita, 1973; 1995; Kmita \& Banaszak 1991). The culture thus is understood as a kind of knowledge, knowledge in the broad sense of what is to be acted on (measures, ways - directive beliefs) in order to achieve a specific objective (value - normative beliefs). The recognized cultural values not only guide our actions but also, as a human creation, are characteristic only of the human world. They are therefore historically variable, situational, temporary and culturally reformed.

The most important tool for studying human activity in this research perspective is the special procedure that allows the reconstruction of the axiological background (normative-directive beliefs) that determines human actions. This procedure is a humanist interpretation, understood as one of the methods of scientific explanation. The humanist interpretation consists of formulating the answer why a given entity undertook such and no other activity, what is the sense of its actions; and why the individual gave the product its specific features. The explanation of this type is based on the assumption about the rationality of the subject (the entity operates in a rational way) and a two-type description. First of all - the reconstruction of knowledge possessed by the acting unit, on the basis of which it undertook activities and which knowledge determines 
the results, products of these activities; secondly - a description of a specific type of value order, indicating the value on which the activity and its product are directed. The explanatory procedure I use is implemented in its critical version - as an adaptive version of the humanist interpretation. In my research, I use knowledge that is certain and available today; today's recognition of specific activities, phenomena, and cultural artifacts. I therefore take into account 'in the expansion of elements of the consciousness of modern people to the interpreter' (Kmita, 1973, p. 219), the cultural competence available today.

\section{Results}

The contemporary definition of truth is directly related to globalization processes, especially in the context of the functioning of global new technologies and challenges in the field of new forms of economic practice. The truth as a technological value is not an autotelically valuable quality of knowledge, but it is a secondary quality, a tool of technological efficiency of cognition. How does globalization affect the new way of redefining the truth, treated as the axiological basis of scientific practice? First of all - social globalization processes related to the popularization of the open social stratification model are the key here. Secondly - the processes of 'technologization' of economic practice that strengthen the technological understanding of truth. My answer is close to - in the context of the reconstruction of knowledge and values as part of the adopted research procedure - the statements made today by many sociologists (Bauman, 2010, pp. 101-135; Giddens, 2006, pp. 120-133; Sztompka, 2012, pp. 45-55), talking about the global functioning of today's societies, representing the so-called Western civilization (Europe and the United States), as technologically oriented (Robbins, 2008; Robertson, 1992, pp. 138-145). The latest economic history of developed societies is an unprecedented exception 'against the background of the history of the past: their population is in the vast majority no longer suffering from hunger and economic uncertainty' (Inglehart, 2006, p. 336). Now the most important is the quality of life not only in reality, but also (or as the most important) in Internet.

The question of quality of life is very important here because it involves the necessity, the human being's terror of making constant choices about their life. Subjected to globalization processes, the postmodern society - unlike the earlier, traditional ones - does not give a specific sense of security to an individual, a sense of stability in the world in which we live and enter into established, as far as social roles that the human being plays throughout their life. We live 'in a situation where many areas of human life are not determined by already existing and ready-made patterns and customs', and 'the individual is forced to work out and negotiate their own lifestyle options', to design themselves, to develop 'reflective identity narration' (Giddens, 2006, p. 126). Technology has greatly overcome the problems faced by man, such as hunger, epidemics and cataclysm, while causing the social world to 'soak up' it spirit, became mar- 
ketized, subordinate to it. The ideology of the free market, based on the category of competitiveness that leads to efficiency, and the idea of technological advances as the most important regulator of human activities have penetrated into all spheres of life. The truth in the context of electoral activities of political spheres and in the context of media activities, based on emotions and individual beliefs, has 'rested' in the post-truth (Laketa, 2019, pp. 155-161); as once Ingarden wrote about Quasi-truth in relation to literary work, so today we can talk about the like-truth created within the narration systems (Picciotto, 2019, pp. 88-96). The socio-cultural changes they have made are so strong that, metaphorically speaking, truth could not and does not remain neutral.

The philosophical proposition on the truth, which I would like to point out as the example of the current cultural transformations, mainly related to the unification of the world in the cultural dimension (consumerism), is the position taken on by Rorty (1999). As we know, the American philosopher rejected the idea of truth in its traditional sense, treating it as one of those key concepts in the final vocabulary, to which its ironists should be distant (Diaconu, 2014, pp. 165-169). So there is no truth-in-itself; the truth is only to say that it is a form of the use of reality, and the opinion of the truth - only that it is the opinion that is considered so. According to Rorty (1999), we hold for valuable and true only those beliefs that turn out to be such a guide to achieving what we want to rely on - they gain 'the value of truth' in the sense of 'being recognized' within solidarity-based conversation, which is addressed to others rather than to reality. As Rorty (1999, p. 20) writes: 'it is necessary to distinguish the claim that the world is outside, from the assertion that the truth is outside (...). To say that truth is not outside, it is just as much as to conclude that where there is no sentence, there is no truth that sentences are elements of human languages, and human languages are the creations of man'. The rejection of the traditional valuation of scientific research practice in the context of the realization of the truth which is self-reliant, makes the actions of scientists and descriptions of the world which they formulate not alone-in-itself better than other descriptions that appear. 'Rorty tends to be visionary of science, which assumes that it 'is only a handmaid of technology'. As part of this learning function, 'great scientists are finding descriptions of the world that are useful for predicting and controlling events' (Kotowa, 2001, p. 155). Truth is therefore understood as a technological value, it is a secondary quality, a tool of technological efficiency of cognition - the only criterion that distinguishes science from what is not science, which Rorty (1999) points out, is 'this characteristic of scientific knowledge, what is the ability to predict (and thus exercise control over a certain slice of reality)' (Kotowa, 2001, p. 155).

The position of the American philosopher on the truth expresses the contemporary cultural urge to continually 'write' ourselves, to make choices (lifestyles), to reconcile, to create an individual, and to change the society of the technologised world. The descriptions of the world, provided by different spheres of social practice (also through research practice), compete with each other and are 
judged by their effectiveness and impact on the quality of life. In the words of $€ a-$ gosz (2014, p. 23): 'the truth that is going on in science, is like Shakespeare's dog 'being taken out to a kennel by a whip'. Her place took the technology'. In my opinion, however, this does not mean the 'death' of truth in scientific cognition. Truth is exterminated as an epistemological myth, as a self-value, its place is occupied by truth understood as a technological value. In research practice, many scientists continue to be guided by the realization of the truth only for itself, but the technological understanding of the value of truth is increasingly 'fittings' in the framework and scientific standards, formulated by institutions of education and science. Research projects are intended to be innovative, creative, competitive, effective and based on competition - as in the free-market ideology.

In my opinion, what contributes to the strengthening of the technological understanding of the truth in science and other sectors of social practice (putting it in the category of efficiency and competitiveness) are contemporary economic practices, disseminated in/through/within/thanks to the Internet. The economics of the network, which 'possessed the world' (Śliwiński, 2015, p. 24), disseminates new patterns of business partners, business relationships, flow of services and transaction security methods. These patterns are shifting to scientific practice - scientists are increasingly turning to specific business models as a strategy to promote the discipline they are dealing with, issues they study, articles (less often books) and authors they read. Since, as a human being, I use services available on the Internet, the technologized world of science is becoming somewhat natural to me as a scientist: the application I use - literature reviews, available for download; number of clicks - number of citations; global brand of the company - Impact Factor etc. As the most important features of global, modern business models related to the strengthening of the technological approach to the truth, I would mention: decentralization/dispersion (blockchain economy), peer-to-peer economy exchange, accessibility, internet platform as a place of brokering (access economy) and immediacy (on-demand economy). Each of these features creates the axiological 'climate' of our activities, each directing our choices not only in the consumer sphere, but also in relation to scientific activities.

Access economy is based on broad access to goods and services. The concept of ownership is rejected, but profit is always indicated as the main idea, giving meaning to the actions taken; this distinguishes access economy from sharing economy (the two are often confused), which indicates value other than profit. Interpreting the activities undertaken by scientists in a humanist way, it can be stated in the expansion that they are on the one hand - aimed at sharing (ideas, thoughts); and on the other - for profit (points, citations). An ideological value that attaches a value to these ideas is truth understood as technological efficiency.

Decentralized trust systems, based on peer-to-peer relationships, operate today (not only in business, although everything started from cryptocurren- 
cies and the idea of Satoshi Nakamoto) as an IT response to market failure, based on centralized trust institutions. The ability to track transactions through the existence of blockchain creates a new way of controlling risk and building trust; in relation to scientific practice, it can be a kind of reliable and honest chance of sharing knowledge based on parity.

Business models of economics on demand, created by digital markets, are based on the ideas of immediacy and simplicity - what counts is time, quick response to a given need and simplicity of the form of exchange (goods, services) so that it is 'fast, easy and pleasant'. Regarding scientific practice, the schemes, methods of knowledge transfer and publication of research results developed (by publishing houses, magazines, all scientific institutions) seem similar instead of intricate, jargon-filled arguments - short, clear messages, instead of monumental studies - specific results research.

\section{Conclusion}

Truth is a cultural value that, despite the historically variable ways of defining it, is universalised, because it is stored in the culture as the backbone of the deposit of value, which has been a socially inherited tradition for generations (its absolute nature is gained through the cultural norm of this value in the lives of individuals and communities). In other words: for the effective functioning of the culture as a whole, functioning that guarantees a direct continuation and/ or prolongation of the developmental trends of the social organism concerned it is necessary to respect, within various areas of culture, certain conditions governing the action taken.

In the article, I researched the cultural background of truth, taking into account the socio-economic-cultural changes that accompanied, or even determined the redefinition of the concept of truth. Thanks to this, it was shown that truth as a value has been and is being universalized, that it is a permanently present, important element of both individual and social thinking and action. With regard to the technological definition of truth, it has been shown: firstly - as the genesis of this definition globalization processes (mainly in socio-economic and cultural dimensions), secondly — the need to take into account the axiological context in relation to new types of economic practice and the impact of this context on contemporary scientific practice.

\section{References}

Andreas, H., \& Schiemer, G. (2016). A choice-semantical approach to theoretical truth. Studies in History and Philosophy of Science: Part A, 58. doi:10.1016/j. shpsa.2016.02.001.

Bauman, Z. (2010). Żyjąc w czasie pożyczonym: rozmowy z Citlali Rovirosa-Madrazo. Warszawa: Wydawnictwo Literackie. 
Diaconu, M. (2014). Truth and knowledge in postmodernism. Procedia: Social and Behavioral Sciences, 137. doi:10.1016/j.sbspro.2014.05.270.

Giddens, A. (2006). Miłość, seks i inne uzależnienia. In P. Sztompka, \& M. Kucia (Eds.), Socjologia: lektury. Kraków: Znak.

Habermas, J. (2002). Teoria dziatania komunikacyjnego. Volume 2. Warszawa: PWN.

Inglehart, R. (2006). Pojawienie się wartości postmaterialistycznych. In P. Sztompka, \& M. Kucia (Eds.), Socjologia: lektury. Kraków: Znak.

James, W. (1983). What pragmatism means? In S.E. Stumpf (Ed.), Philosophy: history and problems. New York: McGraw-Hill.

James, W. (2001). Pragmatism's conception of truth. In M.P. Lynch (Ed.), The nature of truth: classic and contemporary perspectives. Cambridge: Mass MIT Press. doi:10.7551/mitpress/4884.003.0018.

Kmita, J. (1973). Wykłady z logiki i metodologii nauk: dla studentów wydziałów humanistycznych. Warszawa: PWN.

Kmita, J. (1995). Jak stowa tączą się ze światem: studium krytyczne neopragmatyzmu. Poznań: UAM.

Kmita, J., \& Banaszak, G. (1991). Spoteczno-regulacyjna koncepcja kultury. Warszawa: Instytut Kultury.

Kołakowski, L. (2009). Kultura i fetysze. Warszawa: PWN.

Kotowa, B. (2001). Efektywność wiedzy a jej uprawomocnienie. In A. Motycka (Ed.), Wiedza a wartości. Warszawa: PAN.

Kuhn, T.S. (2009). Struktura rewolucji naukowych. Warszawa: Aletheia.

Laketa, S. (2019). 'Even if it didn't happen, it’s true': the fantasy of geopolitics in the 'post-truth' era. Emotion, Space and Society, 31. doi:10.1016/j. emospa.2018.01.002.

Łagosz, M. (2014). Innowacja: nowa królowa Polski. Gazeta Wyborcza, 25-26.01.2014.

Maddy, P. (2007). Second philosophy: a naturalistic method. Oxford: Oxford University Press. doi:10.1093/acprof:oso/9780199273669.001.0001.

Picciotto, R. (2019). Is evaluation obsolete in a post-truth world? Evaluation and Program Planning, 73. doi:10.1016/j.evalprogplan.2018.12.006.

Robbins, R.H. (2008). Globalne problemy a kultura kapitalizmu. Poznań: Pro Publico.

Robertson, R. (1992). Globalization: social theory and global culture. London: Sage. doi:10.4135/9781446280447.

Rorty, R. (1999). Obiektywność, relatywizm i prawda: pisma filozoficzne. Volume 1. Warszawa: Aletheia.

Sztompka, P. (2012). Socjologia: analiza spoteczeństwa. Kraków: Znak.

Śliwiński, A. (2015). Ekonomia sieci: jak globalne sieci opętaty świat? Warszawa: Iota Unum.

Tarski, A. (1995). Pisma logiczno-filozoficzne. Volume 1: prawda. Warszawa: PWN. 
Tuchańska, B. (2012). Dlaczego prawda?: prawda jako wartość w sztuce, nauce i codzienności. Warszawa: Poltext.

Winfield, R.D. (2001). Autonomy and normativity: investigations of truth, right and beauty. Aldershot: Ashgate. doi:10.4324/9781315201627.

Woleński, J. (2007). Epistemologia: poznanie, prawda, wiedza, realizm. Warszawa: PWN.

\section{Acknowledgements}

Author contributions: author has given an approval to the final version of the article.

Funding: this research was funded by the Poznan University of Economics and Business, Faculty of Economics, Department of Sociology and Business Ethics statutory sources.

Note: the results of this study were presented at 8th International Scientific Conference: Contemporary Economic Problems 'Social-economic problems in the era of globalization: theory and practice' (May, 22, 2019, Torun, Poland). 
